\title{
Contamination of chickens by Salmonella spp., in Brazil: an important public health problem
}

Contaminação de frangos comercializados no Brasil por Salmonella spp.: um importante problema de saúde pública Contaminación de pollos comercializados en Brasil por Salmonella spp.: un importante problema de salud publica Francisco Patricio de ANDRADE JÚNIOR ${ }^{1}$ Brenda Tamires de Medeiros LIMA ${ }^{2}$

Thiago Willame Barbosa ALVES ${ }^{2}$

Brencarla de Medeiros LIMA ${ }^{3}$

Laísa Vilar CORDEIRO ${ }^{4}$

\section{Vanessa Santos de Arruda BARBOSA ${ }^{5}$}

Edeltrudes de Oliveira LIMA ${ }^{6}$

${ }^{\prime}$ Master's Degree, Post-Graduate Program in Natural and Synthetic Bioactive Products, Federal University of Paraíba, João Pessoa - PB, Brazil ${ }^{2}$ Graduateds on the Department of Pharmacy, Center of Education and Health, Federal University of Campina Grande, Cuité - PB, Brazil

${ }^{3}$ Graduating in Food Engineering, Agro-Food Science and Technology Center, Federal University of Campina Grande, Pombal - PB, Brazil

${ }^{4}$ Doctor student, Post-Graduate Program in Natural and Synthetic Bioactive Products, Federal University of Paraíba, João Pessoa - PB, Brazil ${ }^{5}$ Center of Education and Health, Federal University of Campina Grande, Cuité - PB, Brazil

${ }^{6}$ Prof ${ }^{a}$. Dr. . and Advisor, Postgraduate Program in Natural and Synthetic Bioactive Products, Federal University of Paraíba, João Pessoa-PB, Brazil \begin{abstract}
Introduction: Bacteria of the genus Salmonella are important pathogens involved in the contamination of various foods, such as chickens, and may cause food poisoning. Aim: The present study aimed to review the literature on the prevalence of chickens contaminated with Salmonella spp., which are commercializated in different Brazilian states. Material and methods: This was a literary review. The absolute frequency and the total percentage of contaminated samples was calculated and the Qui-square statistical test was applied, considering statistically significant $\mathrm{p}<0.05$. Results: 616 publications were retrieved, but only 10 articles were included to compose the results. The cataloged studies were carried out in 14 different brazilian states, and it was observed that of 5,030 chicken samples analyzed, the mean prevalence of samples contaminated with Salmonella was 7,3\% $(\mathrm{n}=365)$. In addition, the prevalence of samples in the different studies ranged from $2.5 \%$ to $44.6 \%$. The most prevalent serotype was S. Enteritidis $(28,7 \%)$ and a statistically significant association between the type of raw material for commercialization and the result of the chicken samples microbiological analysis was observed ( $<<0.001)$, where the carcasses represented $90.1 \%$ of the contaminated samples. Conclusion: Thus, the data presented in this study can serve as subsidy for the development of necessary, political or legislative, measures that allow a better control of commercialized chickens in Brazil.
\end{abstract}

Descriptors: Salmonella; Foodborne Diseases; Epidemiology.

\section{Resumo}

Introdução: Bactérias do gênero Salmonella são importantes patógenos envolvidos na contaminação de diversos alimentos, a exemplo de frangos, podendo ocasionar em intoxicação alimentar. Objetivo: O presente estudo teve como objetivo fazer uma revisão de literatura acerca da prevalência de frangos contaminados por Salmonella spp., comercializados em diferentes estados brasileiros. Material e métodos: Tratouse de uma revisão literária. Analisou-se a frequência absoluta e calculou-se o percentual total de amostras contaminadas; o teste QuiQuadrado foi aplicado, considerando $\mathrm{p}<0,05$ estatisticamente significativo. Resultados: Na revisão de literatura houve a recuperação de 616 publicações, porém somente 10 artigos foram incluídos para compor os resultados. Os estudos catalogados foram realizados em 14 estados distintos, e foi observado que de 5.030 amostras de frango analisadas, a prevalência média de amostras contaminadas por Salmonella foi de $7,3 \%(\mathrm{n}=365)$. Além disso, a prevalência de amostras nos diferentes estudos variou entre 2,5\% a 44,6\%. O sorotipo mais prevalente foi $S$. Enteritidis $(28,7 \%)$ e associação estatisticamente significativa, entre o tipo de matéria prima para comercialização e o resultado da análise microbiológica das amostras de frango foi observada ( $<<0,001$ ), em que as carcaças representaram $90,1 \%$ das amostras contaminadas. Conclusão: Assim, os dados apresentados neste estudo podem servir de subsídio para o desenvolvimento de medidas cabíveis, sejam elas políticas ou legislativas, que permitam maior fiscalização dos frangos comercializados no Brasil.

Descritores: Salmonella; Doenças Transmitidas por Alimentos; Epidemiologia.

\section{Resumen}

Introducción: las bacterias del género Salmonella son patógenos importantes involucrados en la contaminación de varios alimentos, como los pollos, y pueden causar intoxicación alimentaria. Objetivo: El objetivo de este estudio fue revisar la literatura sobre la prevalencia de Salmonella spp. en pollos contaminados comercializados en diferentes estados brasileños. Material y métodos: se trata de una revisión literaria. Se analizó la frecuencia absoluta y se calculó el porcentaje total de muestras contaminadas; Se aplicó la prueba de chi-cuadrado, considerando p <0.05 estadísticamente significativo. Resultados: En la revisión de la literatura recuperó 616 publicaciones, pero solo se incluyeron 10 artículos para componer los resultados. Los estudios catalogados se realizaron en 14 estados diferentes, y se observó que de 5.030 muestras de pollo analizadas, la prevalencia promedio de muestras contaminadas con Salmonella fue del 7.3\% (n=365). Además, la prevalencia de muestras en diferentes estudios varió de $2.5 \%$ a $44.6 \%$. El serotipo más prevalente fue $S$. Enteritidis (28.7\%) y se observó una asociación estadísticamente significativa entre el tipo de materia-prima para comercialización y el resultado del análisis microbiológico de muestras de pollo ( $\mathrm{p}<0.001$ ), donde los cadáveres representaron 90,1\% de muestras contaminadas. Conclusión: Por lo tanto, los datos presentados en este estudio pueden usarse como un subsidio para el desarrollo de medidas apropiadas, ya sean políticas o legislativas, que permitan una mayor supervisión de los pollos de engorde comercializados en Brasil.

Descriptores: Salmonella; Enfermedades Transmitidas por los Alimentos; Epidemiología.

\section{INTRODUCTION}

The poultry industry is responsible for the supply of meats and products derived from poultry, with an annual production of over 106 million tons and presenting as one of the main difficulties the control of microorganisms in their products, such as chicken meat ${ }^{1-3}$.

In the nutritional aspect, chicken meat is an excellent source of protein, B complex, vitamins and minerals. However, due to its intrinsic characteristics such as high nutrient content, high water activity, $\mathrm{pH}$ near neutrality and meat storage sites, this favors the growth of microorganisms such as bacteria of the genus Salmonella ${ }^{4}$.

Salmonella genus is characterized by rodshaped bacteria, belonging to the family Enterobacteriaceae, mobile, facultative anaerobic and non-spore-producing. In addition, these microorganisms are extremely important for public health 
since they are used worldwide for the determination of food microbiological standards $s^{1,5,6}$.

In Brazil, the prevalence data and microbial ecology of Salmonella spp., in the chicken commercialization process are scattered and inconclusive. However, these bacteria are among the main responsible for outbreaks of foodborne diseases, which can lead to bacteremia, gastroenteritis or even enteric fever ${ }^{5,7}$.

Thus, the present study aimed to review the literature on the prevalence of chickens contaminated with Salmonella spp., which are commercializated in different Brazilian states.

\section{MATERIAL AND METHOD}

- Study Design

It was a literary review allowing, therefore, the synthesis of certain information taken from previously published studies that are pertinent to the theme.

\section{- Inclusion and exclusion criteria}

Were included studies that investigated the presence of Salmonella spp., in chickens that were available for commercialization in different Brazilian states and published between the years of 2008 and 2018. Researches conducted in other countries or published outside the delimited period were excluded from the study.

\section{- Information sources}

The articles were retrieved from the databases: Lilacs (Latin American and Caribbean Center on Health Sciences), Scielo (Scientific Electronic Library Online) and PubMed. Data collection occurred between November 2018 and June 2019. The last update occurred on June 20, 2019.

\section{- Search strategy}

The search strategy used to find articles in the databases was based on the use of the following descriptors and keywords: "Salmonella", "Chicken" and "Brazil".

\section{- Data extraction}

The following variables were extracted: author(s), year, Brazilian federative unit, raw material type, total of samples analyzed, total samples contaminated by Salmonella and Salmonella serotypes found.

\section{- Statistical analysis}

The absolute number of the investigated samples was analyzed and the percentage of samples contaminated by Salmonella was determined for each of the studies. In addition, the average prevalence of chickens contaminated by bacteria of this genus and the serotypes percentage found was calculated. The statistical association was performed through the Statistical Package for Social Sciences (SPSS) version 13.0, using the Qui-square statistical test, where it was considered statistically significant when $\mathrm{p}<0.05$ for rejection of null hypotheses.

\section{RESULTS AND DISCUSSION}

In literature review, 616 publications were retrieved, but only 10 articles were included to compose the results. The table below shows the prevalence of Salmonella spp., in chickens commercialized in different Brazilian states (Table 1).

Table 1. Prevalence of Salmonella in chickens commercialized in different Brazilian states in studies published between the years 20082018

\begin{tabular}{|c|c|c|c|c|}
\hline $\begin{array}{l}\text { Author and } \\
\text { year }\end{array}$ & $\begin{array}{c}\text { Federative } \\
\text { unit }\end{array}$ & $\begin{array}{c}\text { Type of } \\
\text { raw } \\
\text { material }\end{array}$ & $\begin{array}{c}\text { Total of } \\
\text { analyzed } \\
\text { samples }\end{array}$ & $\begin{array}{c}\text { Total samples } \\
\text { contaminated } \\
\text { with } \\
\text { Salmonella }\end{array}$ \\
\hline $\begin{array}{l}\text { Borsoi et al. } \\
2010^{8}\end{array}$ & $\begin{array}{l}\text { Rio Grande do } \\
\text { Sul }\end{array}$ & Carcasses & 180 & $22(12,2 \%)$ \\
\hline $\begin{array}{c}\text { Cardoso et al. } \\
2009^{9}\end{array}$ & São Paulo & $\begin{array}{c}\text { Meat cuts } \\
\text { (chicken } \\
\text { breast) }\end{array}$ & 112 & $36(32,1 \%)$ \\
\hline $\begin{array}{l}\text { Cunha Neto et } \\
\text { al., } 2018^{10}\end{array}$ & Mato Grosso & Carcasses & 850 & $31(3,6 \%)$ \\
\hline $\begin{array}{c}\text { Duarte et al. } \\
2009^{11}\end{array}$ & $\begin{array}{c}\text { Brazilian } \\
\text { Northeast }\end{array}$ & Carcasses & 260 & $25(9,6 \%)$ \\
\hline $\begin{array}{c}\text { Medeiros et al. } \\
2011^{12}\end{array}$ & $\begin{array}{c}\text { Amapá, Ceará, } \\
\text { Rio Grande do } \\
\text { Norte, Alagoas, } \\
\text { Minas Gerais, } \\
\text { Espírito Santo, } \\
\text { Rio de Janeiro, } \\
\text { São Paulo, } \\
\text { Goiás, Distrito } \\
\text { Federal, Mato } \\
\text { Grosso do Sul, } \\
\text { Paraná, Santa } \\
\text { Catarina, Rio } \\
\text { Grande do Sul. }\end{array}$ & Carcasses & 2679 & $73(2,7 \%)$ \\
\hline $\begin{array}{c}\text { Menezes et al. } \\
2018^{13}\end{array}$ & Minas Gerais & Carcasses & 240 & $22(9,2 \%)$ \\
\hline $\begin{array}{l}\text { Moreira et al. } \\
2008^{14}\end{array}$ & Goiás & Carcasses & 363 & $52(14,3 \%)$ \\
\hline $\begin{array}{l}\text { Possebon et al. } \\
2012{ }^{15}\end{array}$ & São Paulo & Carcasses & 130 & $58(44,6 \%)$ \\
\hline $\begin{array}{c}\text { Tessari et al. } \\
2008^{16}\end{array}$ & São Paulo & Carcasses & 116 & $3(2,5 \%)$ \\
\hline $\begin{array}{c}\text { Yamatogi et al. } \\
2011^{17}\end{array}$ & São Paulo & Carcasses & 100 & $43(43 \%)$ \\
\hline Total & & & 5,030 & $365(7,3 \%)$ \\
\hline
\end{tabular}

The cataloged studies were carried out in 14 different states, where the average prevalence of Salmonella contamination was $7,3 \%(n=365)$ of the 5,030 chicken samples analyzed. In addition, the prevalence of contaminated samples in the different studies ranged from $2.5 \%$ to $44.6 \%$.

Similar results were observed in the cities of the states of Uttarakhand and Uttar Pradesh, India. In several chicken samples for commercialization, the prevalence of this bacterium in the chicken meat samples was $14.9 \%$ (28/188), being significantly higher when compared to samples of chicken feces $(7,0 \%, 15 / 214)$ and environmental $(7.9 \%, 27 / 340)$ with a value of $\mathrm{p}<0.01$ [18]. The result of this study is similar to that of Harb et al. ${ }^{19}$ carried out in ThiQar, southeastern Iraq, where $11.5 \%$ of a total of 400 frozen chicken carcasses were contaminated with Salmonella. In Singapore, among the 270 chicken meat samples collected for analysis, 49 were contaminated with Salmonella, resulting in a prevalence of $18.1 \%^{20}$.

Differently, in Malaysia, higher prevalences were observed. It was noted that of the 35 chicken carcasses analyzed, $48 \%$ were contaminated by Salmonella. ${ }^{21}$ In China, a 12-month study was 
conducted between 2011 and 2012, in which 1595 freshly slaughtered, chilled and frozen chicken carcasses were collected from supermarkets in various provinces. From the analyzes, it was found that $41.6 \%$ of the samples were contaminated by Salmonella ${ }^{22}$.

Smaller prevalences, when compared with the average prevalence found in our study, were observed in Estonia, where a survey conducted between 2008 and 2013 revealed that most food products contaminated with Salmonella are those that do not receive heat treatment, including broiler meat $(4 \%, 7 / 175)$ and chicken meat $(2,2 \%, 11 / 496)^{23}$. Table 2 shows the statistical association between the raw material and Salmonella contamination.

Table 2. Statistical association between the type of raw material for commercialization and the result of the microbiological analysis of the chicken samples

\begin{tabular}{c|c|c|c|c|c}
\hline \multirow{2}{*}{ Raw material } & \multicolumn{2}{|c|}{$\begin{array}{c}\text { Uncontaminat } \\
\text { ed samples }\end{array}$} & \multicolumn{2}{c|}{$\begin{array}{c}\text { Contaminate } \\
\text { d samples* }\end{array}$} & \multirow{2}{*}{$\boldsymbol{p}$} \\
\cline { 2 - 5 } & $\mathbf{n}$ & $\%$ & $\mathbf{n}$ & $\mathbf{9}$ & \\
\hline Meat cuts** & 76 & 1.6 & 36 & 9.9 & \multirow{2}{*}{$<0,001$} \\
\hline Carcass & 4,589 & 98.4 & 329 & 90.1 & \\
\hline Total & 4,665 & 100 & 365 & 100 & \\
* Positive samples for Salmonella; ** Chicken breast \\
Source: Research data, 2019
\end{tabular}

It was observed a statistically significant association between the type of raw material for commercialization and the result of the microbiological analysis of the chicken samples, in which the predominance of contaminated carcasses $(90.1 \%)$ was evidenced. That result is understandable since, even before the marketing stage, the chickens may already be contaminated.

In addition, it has been elucidated that this bacteria can be detected during production, processing, distribution and handling, as well as at all stages of slaughtering, especially in pre-cooling and evisceration, where more contaminated carcasses are generally observed ${ }^{5,24}$. However, environmental factors such as temperature may contribute. The temperature and its impact on the growth kinetics of Salmonella have a directly related effect on the proliferation and maintenance of the bacteria in the food $^{24}$. It is observed that in chicken cuts Salmonella development can be initiated from $16^{\circ} \mathrm{C}^{4}$. Figure 1 shows the prevalence of different Salmonella spp., serotypes found in the investigated studies.

$S$. Enteritidis is a facultative intracellular pathogen responsible for food poisoning in humans called salmonellosis and was the most prevalent serotype $(28.7 \%)$ in this study. In addition, it has been evidenced that the contamination of chickens by this pathogen, especially in carcasses, is related to the broiler chickens environment that may be contaminated, allowing the dissemination of this bacteria soon after slaughter ${ }^{25,26}$. In addition, contamination of chickens by this bacterial genus can also occur through the manipulators contaminated hand or contact with feces and contaminated water.

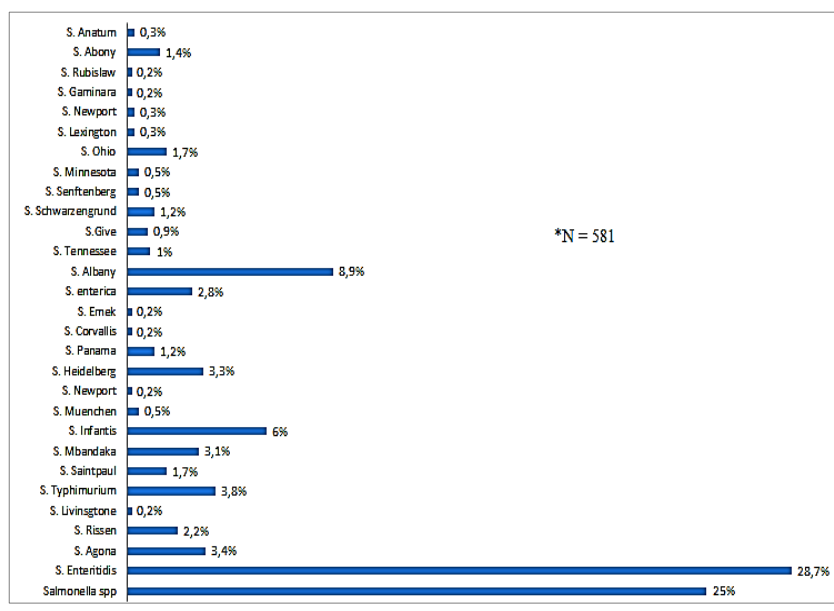

Figura 1: Prevalence of different serotypes of Salmonella spp., found in commercialized chicken in different Brazilian states in studies published between the years 2008-2018.

Those infected by this serotype may present gastrointestinal infection, whose symptoms, such as abdominal pain, diarrhea, low fever and vomiting, appear about 12 to 36 hours and may last up to 72 hours, however, clinical cases that evolve to fatality are $\operatorname{rare}^{27,28}$.

In addition, $S$. Enteritidis has been associated with cases of self-limited enterocolitis in high-class population and one of the main causes of death in places where extreme poverty exists, such as subSaharan Africa. In immunocompromised patients with salmonellosis, on the other hand, is one of the main responsible for causing infections and septemias $^{29}$.

It was recorded that, in $25.0 \%$ of the findings, they did not present the Salmonella serotype identification, which may contribute to the lack of understanding of the epidemiological characteristics of this type of bacteria in chickens. This makes it difficult to develop more specific public policies to combat these pathogens since there is no knowledge of the epidemiological situation of the country, relating to different foods, serotypes and bacterial species.

\section{CONCLUSION}

Taking into account the period selected for the recovery of the data presented in this study, it can be inferred that it is a subject scarcely explored, considering the number of studies performed and the Brazilian states contemplated. This masks the real problem magnitude.

However, it was observed that $7,3 \%$ of the samples collected in this study were contaminated by Salmonella, with the S. Enteritidis serotype being the most prevalent, which presents a considerable risk to the health of those consumed who may consume these contaminated foods.

Finally, it is important to carry out this type 
study, in order to show this problem, as well as to serve as a subsidy for the development of appropriate, political or legislative, measures that improve this panorama.

\section{REFERENCES}

1. Souza GC, Gonsalves HRO, Gonsalves HEO, Coêlho JLS. Característica microbiológica da carne de frango. ACSA. 2014;10(1):12-17.

2. Pinto LAM, Pinto MM, Bovo J, Mateus GAP, Tavres FO, Baptista ATA, et al. Aspectos ambientais do abate de aves: uma revisão. Rev Uningá. 2018;22(3):44-50.

3. Oliveira ME, Oliveira RLZ, Souza MFLZ, Harada ES, Tech ARB. Desenvolvimento de sensores para monitoramento de ambiente aviário com ênfase em controle térmico. Int J Agric \& Biol Eng. 2018;12(3):234-40.

4. Cintra APR, Andrade MCG, Lazarini MM, Assis DCS, Silva GR, Menezes LDM, et al. Influence of cutting room temperature on the microbiological quality of chicken breast meat. Arq Bras Med Vet Zootc. 2016;68(3):814-20.

5. Rückert DAS, Pinto PSA, Santos BM, Moreira MAS, Rodrigues ACA. Pontos críticos de controle de Salmonella spp. no abate de frangos. Arq Bras Med Vet Zootec. 2009;61(2):326-30.

6. Oliveira AP, Sola MC, Feistel JC, Moreira NM, Oliveira JJ. 2013. Salmonella enterica: genes de virulência e ilhas de patogenicidade. Enciclopedia Biosfera. 2013;9(16):1947-72.

7. Brasil. Ministério da Saúde [homepage na internet]. Surtos de doenças transmitidas por alimentos no Brasil [acesso em 15 jul 2018]. Disponível em: http://portalarquivos2.saude. gov.br/images/pdf/2018/julho/02/Apresentacao-

Surtos-DTA-Junho-2018.pdf.

8. Borsoi A, Moraes HLS, Salle CTP, Nascimento VP. Número mais provável de Salmonella isoladas de carcaças de frango resfriadas. Ciênc Rural. 2010;40(11):2338-42.

9. Cardoso KF, Rall VLM, Mendes AA, Paz ICLA, Komiyama CM. Pesquisa de salmonella e coliformes termotolerantes em cortes de frango obtidos no comércio de Botucatu/SP. Hig Aliment. 2009;23(176/179):165-68.

10. Cunha-Neto AD, Carvalho LA, Carvalho RCT, Dos Prazeres Rodrigues D, Mano SB, Figueiredo EES, Conte-Junior CA. Salmonella isolated from chicken carcasses from a slaughterhouse in the state of Mato Grosso, Brazil: antibiotic resistance profile, serotyping, and characterization by repetitive sequence-based PCR system. Poult Sci. 2018;97(4):1373-81.

11. Duarte DAM, Ribeiro AR, Vasconcelos AMM, Santos SB, Silva JVD, Andrade PLA, et al. Occurrence of Salmonella spp. in broiler chicken carcasses and their susceptibility to antimicrobial agents. Braz J Microbiol. 2009;40(3):569-73.
12. Medeiros MA, Oliveira DC, Rodrigues DP, Freitas DR. Prevalence and antimicrobial resistance of Salmonella in chicken carcasses at retail in 15 Brazilian cities. Rev Panam Salud Publica. 2011;30(6):555-60.

13. Menezes LDM, Lima AL, Pena EC, Silva GR, Klein RWT, Silva CA, et al. Caracterização microbiológica de carcaças de frangos de corte produzidas no estado de Minas Gerais. Arq Bras Med Vet Zootec. 2018;70(2):623-27.

14. Moreira GN, Rezende CSM, Carvalho RN, Mesquita SQP, Oliveira AN, Arruda MLT. Ocorrência de Salmonella sp. em carcaças de frangos abatidose comercializados em municípios do estado de Goiás. Rev Inst Adolfo Lutz. 2008;67(2):126-30.

15. Possebon FS, Costa LFZP, Yamatogi RS, Rodrigues MV, Sudano MJ, Pinto JPAN. A refrigeração no diagnóstico de Salmonella spp. utilizando o método microbiológico tradicional e reação em cadeia da polimerase em carcaças de frango. Ciênc Rural. 2012;42(1):131-35.

16. Tessari ENC, Cardoso ALSP, Kanashiro AMI, Stoppa GFZ, Luciano RL, Castro AGM. Ocorrência de Salmonella spp. em carcaças de frangos industrialmente processadas procedentes de explorações industriais do Estado de São Paulo, Brasil. Cienc Rural, 2008; 38(9):2557-60.

17. Yamatogi RS, Galvão JA, Baldini ED, Souza Júnior LCT, Rodrigues MV, Pinto JPAN. Avaliação da unidade analítica na detecção de Salmonella spp. em frangos a varejo. Rev Inst Adolfo Lutz. 2011;70(4):637-40.

18. Sharma J, Kumar D, Hussain S, Pathak A, Shukla M, Kumar VP, et al. Prevalence, antimicrobial resistence and virulence genes characterization of montyphoidal Salmonella isolated from retail chicken meat shops in Northern India. Food Control. 2019;102:104-11.

19. Harb A, Babib I, Mezal EH, Kareem HS, Laird T, O'dea $\mathrm{M}$, et al. Ocurrence, antimicrobial resistence and whole-genome sequencing analysis of Salmonella isolates from chicken carcasses imported into Iraq from four different countries. Int J Food Microbiol. 2018;284:84-90.

20.Zwe YH, Yentang VC, Aung KT, Gutiérrez RA, $\mathrm{Ng}$ LC, Yuk HG. Prevalence, sequence types, antibiotic resistance and, gyrA mutations of Salmonella isolated from retail fresh chicken meat in Singapore. Food Control. 2018;90:233-40.

21. Goni AM, Effarizah ME, Rusul G. Prevalence, antimicrobial resistance, resistance genes and class 1 integrons of Salmonella serovars in leafy vegetables, chicken carcasses and related processing environments in Malaysian fresh food markets. Food Control. 2018;91:170-80.

22. Zhu J, Wang Y, Song X, Cui S, Xu H, Yang B, et al. Prevalence and quantification of Salmonella 
contamination in raw chicken carcasses at the retail in China. Food Control. 2014;44:198-202.

23. Kramarenko T, Nurmoja I, Karssin A, Meremae K., Horman A, Roasto M. The prevalence and serovar diversity of Salmonella in various food products in Estonia. Food Control. 2014;42:43-7.

24. Smadi H, Sargeant JM, Shannon HS, Raina P. Growth and inactivation of Salmonella at low refrigerated storage temperatures and thermal inactivation on raw chicken meat and laboratory media: Mixed effect meta-analysis. Journal of Epidemiology and global Health. 2012;2(4):165-79.

25. Cardoso ALSP, Tessari ENC. Salmonella enteritidis em aves e na saúde pública: revisão da literatura. R cient eletr Med Vet. 2013;11(21).

26. Realpe-Delgado ME, Muñoz-Delgado AB, Donado-Godoy P, Rey-Ramírez LM, DíazGuevara PL, Arévalo-Mayorga SA. Epidemiología de Salmonella spp., Listeria monocytogenes y Campylobacter spp., en la cadena productiva avícula. Iatreia. 2016;22(4):397-406.

27. Shinohara NKS, Barros VB, Jimenez SMC, Machado ECL, Dutra RAF, Lima Filho JL. Salmonella spp., importante agente patogênico veiculado em alimentos. Ciênc. sáude coletiva. 2008;13(5):1675-83.

28. Lv S, Si W, Yu S, Li Z, Wang X, Chen L, Zhang W, Liu S. Characteristics of invasion-reduced hilA gene mutant of Salmonella Enteritidis in vitro and in vivo. Res Vet Sci. 2015;101:63-8.

29. Feasey NA, Hadfield J, Keddy KH, Dallman TJ, Jacobs J, Deng X, et al. Distinct Salmonella Enteritidis lineages associated with enterocolitis in high-income settings and invasive disease in low-income settings. Nat Genet. 2014;48(10):1211-17.

\section{CONFLICTS OF INTERESTS}

The authors declare no conflicts of interests.

\section{CORRESPONDING AUTHOR}

\section{Francisco Patricio de Andrade Júnior}

Post-Graduate Program in Natural and Synthetic Bioactive Products

Federal University of Paraíba, João Pessoa - PB, Brazil

e-mail: juniorfarmacia.ufcg@ outlook.com 